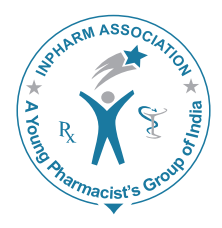

\title{
Quantitative determination of donepezil hydrochloride by a simple and accurate synchronous spectrofluorimetric method in human plasma
}

\author{
Chintan Patel, Nrupesh Patel, Charmy Kothari* \\ Department of Pharmaceutical Analysis, Institute of Pharmacy, Nirma University, Ahmedabad, Gujarat, India
}

\begin{abstract}
Aim: The aim of the study was to develop and validate a new simple, accurate, sensitive and specific bioanalytical spectrofluorimetric method for quantitative determination of donepezil hydrochloride (DH) in human plasma. Method: Estimation of DH in human plasma was done by spiked human plasma studies. Forestimation of DH in human plasma extraction was carried out using 5\% TCA forprotein precipitation followed by liquid-liquid extraction with 5\% IPA in $\mathrm{n}$-Hexane. Under spectrofluorimetric conditions delta value 65 applied in synchronous mode(medium sensitivity mode) and wavelength used in analysis was $389 \mathrm{~nm}$. Result: Developed method found linear, in the concentration range of 50-105 ng/mL with correlation coefficient $\left(R^{2}\right)$ 0.9965. Percentage recovery was found to be $75 \%-85 \%$ for $\mathrm{DH}$. High recovery show that the method is free from the interference from plasma constituents. Conclusion: Proposed method can be used for estimation of $\mathrm{DH}$ in routine quality control laboratories for quantitative determination of $\mathrm{DH}$ in bulk as well as in human plasma. Further it can also be used to determine plasma $\mathrm{DH}$ concentration in drug monitoring or in pharmacokinetic investigations.
\end{abstract}

Key words: Bioanalytical method, donepezil hydrochloride, human plasma, synchronous spectrofluorimetry

\section{INTRODUCTION}

Donepezil is chemically (RS)-2-[(1-benzyl-4-piperidyl) methyl]-5,6-dimethoxy-2,3-dihydroinden-1-one. ${ }^{1,2}$ Donepezil hydrochloride (DH) is a specific and reversible inhibitor of acetylcholinesterase, and used in the treatment of Alzheimer's disease ${ }^{3}$ (Figure 1).

\begin{tabular}{|c|c|}
\hline \multicolumn{2}{|c|}{ Access this article online } \\
\hline Journal Sponsor & \multirow[b]{2}{*}{$\begin{array}{l}\text { Website: } \\
\text { www.jyoungpharm.org }\end{array}$} \\
\hline \multirow{2}{*}{ wuw.phcog net } & \\
\hline & $\begin{array}{l}\text { DOI: } \\
\text { 10.5530/jyp.2014.4.8 }\end{array}$ \\
\hline
\end{tabular}

Literature review of DH reveals that ultraviolet (UV)visible spectrophotometry method in tablet dosage form, ${ }^{4}$ HPLC methods in tablets, ${ }^{5,6}$ HPLC methods in human plasma, ${ }^{7}$ HPLC method in human and rat plasma, blood and microdialysates, ${ }^{8}$ liquid chromatographymass spectrometry (LC-MS)-MS method, ${ }^{9-11}$ HPTLC method in tablet dosage for $\mathrm{m}^{12}$ and enantiomers separation by HPLC method and its application in pharmacokinetics ${ }^{13}$ methods were being reported for the estimation of $\mathrm{DH}$ in biological samples and in tablet dosage form.

However, there is no method reported till now for the estimation of $\mathrm{DH}$ in human plasma by spectrofluorimetric method. The aim of this work was to develop a validated,

*Address for correspondence:

Dr. Charmy S Kothari, Department of Pharmaceutical Analysis, Institute of pharmacy, Nirma University, Sarkhej-Gandhinagar Highway, Chandlodia, Gota, Ahmedabad-382 481.Gujarat, India.E-mail: charmyshah@gmail.com 


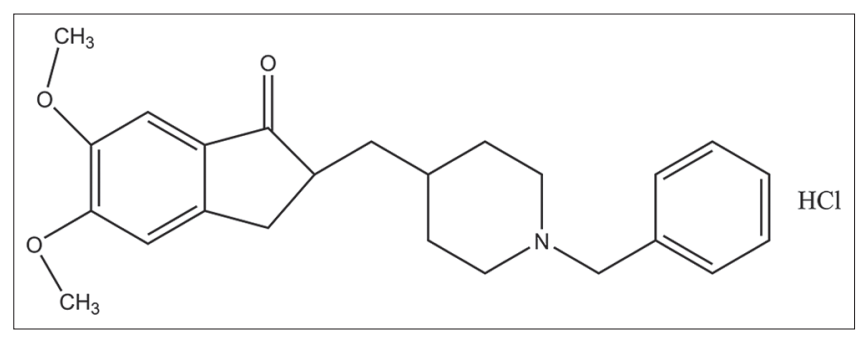

Figure 1: Structure of donepezil hydrochloride

sensitive, specific and simple, accurate, and time saving spectrofluorimetric method for the determination of $\mathrm{DH}$ in human plasma.

\section{MATERIALS AND METHODS}

\section{Instrument}

Spectrofluorimeter Model: FP-6500 PC series, Matched quartz cell $(1 \mathrm{~cm})$, Wavelength range: $220.00-750.00 \mathrm{~nm}$, JASCO Japan.

\section{Chemicals and reagents}

API of DH was kindly gifted by INTAS Pharmaceuticals, Ahmedabad, Gujarat. Boric Acid, potassium chloride, sodium hydroxide, trichloroacetic acid (TCA), perchloric acid, N-Hexane, Iso-Propyl Alcohol, (AR Grade, S.D. Fine Chemicals Ltd., Mumbai, India) were used. Blank Human Plasma was kindly gifted by Prathma Blood Bank, Ahmedabad, Gujarat.

Glassware used in each procedure were soaked overnight in a chromic mixture $\left(\mathrm{K}_{2} \mathrm{Cr}_{2} \mathrm{O}_{7}+\right.$ concentrated $\left.\mathrm{H}_{2} \mathrm{SO}_{4}\right)$, rinsed thoroughly with double distilled water and dried in dust-free air. Whatman filter paper no. 42 was used to filter the MEM solution to separate them from the precipitated proteins and debris.

\section{Experimental}

\section{Preparation of standard stock solution of $\mathrm{DH}$}

DH $(25 \mathrm{mg})$ was accurately weighed and transferred to separate $25 \mathrm{~mL}$ volumetric flasks. Dissolved in $10 \mathrm{~mL}$ double distilled water, sonicated for $10 \mathrm{~min}$ and volume made up to mark with double distilled water to obtain standard stock solution having concentration $1000 \mu \mathrm{g} / \mathrm{mL}$. A volume of $5 \mathrm{~mL}$ aliquot from this solution transferred to $50 \mathrm{~mL}$ volumetric flask and volume made up with double distilled water to obtain working standard stock solution of $100 \mu \mathrm{g} / \mathrm{mL}$.
Preparation of borate buffer $\mathrm{pH}$ (9.6)

Boric acid $(3.09 \mathrm{~g})$ and potassium chloride $(3.73 \mathrm{~g})$ were accurately weighed and transferred to $250 \mathrm{~mL}$ volumetric flask. Volume was made up with distilled water. Then solution was transferred to $1000 \mathrm{~mL}$ beaker and $\mathrm{pH}$ of the solution adjusted to 9.6 by addition of $0.2 \mathrm{M}$ of Sodium hydroxide solution. Then $\mathrm{pH}$ adjustment volume was made up $1000 \mathrm{~mL}$ with distilled water.

\section{Extraction procedure}

A volume of $500 \mu$ l of plasma sample was taken in $2 \mathrm{~mL}$ microcentrifuge tube, then $50 \mu \mathrm{l}$ of drug solution was spiked and $500 \mu \mathrm{l}$ of $5 \%$ TCA solution was added. It was centrifuged for $3 \mathrm{~min}$ at $5000 \mathrm{rpm}$, then supernatant was transferred in another $2 \mathrm{~mL}$ microcentrifuge tube and $100 \mu \mathrm{l}$ of $0.1 \mathrm{~N} \mathrm{NaOH}$ solution to make supernatant alkaline. To this microcentrifuge tube, $1 \mathrm{~mL}$ of $5 \%$ IPA in n-Hexane solution was added and centrifuged for $3 \mathrm{~min}$ at $8000 \mathrm{rpm}$ and upper organic phase was separated and remaining aqueous phase was again centrifuged with $1 \mathrm{~mL}$ $5 \%$ IPA in n-Hexane solution, and upper organic phase was separated and both organic phases were taken in $10 \mathrm{~mL}$ volumetric flask and evaporated to dryness. Then reconstituted with borate buffer to make up a volume of $10 \mathrm{~mL}$ and analyzed by spectrofluorimeter.

\section{Spectrofluorimetric condition}

From the working standard solution, $1 \mu \mathrm{g} / \mathrm{mL}$ solution was prepared by appropriate dilution using diluent and scanned in the synchronous mode with a delta value 65 (medium sensitivity mode) from 220 to $680 \mathrm{~nm}$. From the synchronous spectra of DH, $389 \mathrm{~nm}$ wavelength was selected for measurement of fluorescence intensity of DH (Figure 2).

\section{Method validation}

\section{Linearity}

For preparation of calibration curve of $\mathrm{DH}, 500 \mu \mathrm{L}$ of blank plasma was spiked with $50 \mu \mathrm{L}$ of drug solutions of concentration of $1 \mu \mathrm{g} / \mathrm{mL}, 5 \mu \mathrm{g} / \mathrm{mL}, 9 \mu \mathrm{g} / \mathrm{mL}, 13 \mu \mathrm{g} / \mathrm{mL}$, $17 \mu \mathrm{g} / \mathrm{mL}$, and $21 \mu \mathrm{g} / \mathrm{mL}$ to get the final concentration of $5 \mu \mathrm{g} / \mathrm{mL}, 25 \mu \mathrm{g} / \mathrm{mL}, 45 \mu \mathrm{g} / \mathrm{mL}, 65 \mu \mathrm{g} / \mathrm{mL}, 85 \mu \mathrm{g} / \mathrm{mL}$, and $105 \mu \mathrm{g} / \mathrm{mL}$, respectively. Then extraction was performed as discussed in extraction procedure and then fluorescence intensity of prepared solutions was measured at emission wavelength of $389 \mathrm{~nm} .{ }^{14,15}$

\section{Precision}

Intra-day and inter-day precision was determined by measuring the fluorescence intensity of DH 3 times within a 


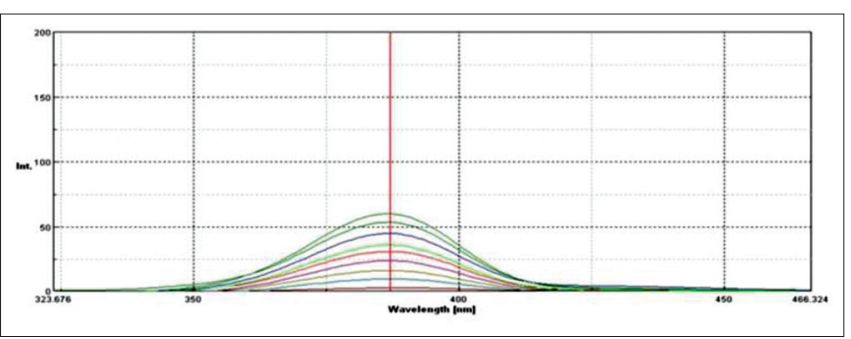

Figure 2: Overlay synchronous spectra of donepezil hydrochloride in spiked human plasma $(5-105 \mu \mathrm{g} / \mathrm{mL})$

day and on three different days, respectively. For intra-day and inter-day precision, intra-day precision $25,65,105 \mu \mathrm{g} / \mathrm{mL}$ were selected. $500 \mu \mathrm{L}$ of blank plasma was spiked with $50 \mu \mathrm{L}$ of drug solution of concentration of $5 \mu \mathrm{g} / \mathrm{mL}, 13 \mu \mathrm{g} / \mathrm{mL}$, $21 \mu \mathrm{g} / \mathrm{mL}$ to get the final concentration of $25 \mu \mathrm{g} / \mathrm{mL}$, $65 \mu \mathrm{g} / \mathrm{mL}$, and $105 \mu \mathrm{g} / \mathrm{mL}$, respectively. Then extraction was performed as discussed in extraction procedure and then fluorescence intensity of prepared solutions was measured at emission wavelength of $389 \mathrm{~nm} .{ }^{14,15}$

\section{Recovery}

A volume of $500 \mu \mathrm{L}$ of blank plasma was spiked with $50 \mu \mathrm{L}$ of drug solutions of concentration of $1 \mu \mathrm{g} / \mathrm{mL}$, $5 \mu \mathrm{g} / \mathrm{mL}, 9 \mu \mathrm{g} / \mathrm{mL}, 13 \mu \mathrm{g} / \mathrm{mL}, 17 \mu \mathrm{g} / \mathrm{mL}$, and $21 \mu \mathrm{g} / \mathrm{mL}$ to get the final concentration of $5 \mu \mathrm{g} / \mathrm{mL}, 25 \mu \mathrm{g} / \mathrm{mL}$, $45 \mu \mathrm{g} / \mathrm{mL}, 65 \mu \mathrm{g} / \mathrm{mL}, 85 \mu \mathrm{g} / \mathrm{mL}$, and $105 \mu \mathrm{g} / \mathrm{mL}$, respectively. Then extraction was performed as discussed in extraction procedure and then fluorescence intensity of prepared solutions was measured at emission wavelength of $389 \mathrm{~nm}^{.14,15}$

\section{Limit of detection and quantification (LOD and LOQ)}

The sensitivity of the analytical method was evaluated by determining the LOD and LOQ. LOD and LOQ were calculated and reported using the following equation.

$\mathrm{LOD}=3.3 \mathrm{X} \sigma / \mathrm{s}$ and $\mathrm{LOQ}=10 \mathrm{X} \sigma / \mathrm{s}$

Where, $\sigma=$ standard deviation of the intercept and $\mathrm{s}=$ slope of the calibration curve.

\section{RESULT AND DISCUSSION}

\section{Optimization of experimental conditions}

Initially, extraction of $\mathrm{DH}$ was carried out with the help of protein precipitation by TCA. But their synchronous spectrum was exceeding the limit of fluorescence intensity (1000 unit). Therefore, extraction of DH by only protein precipitation was not sufficient for proposed method.
Hence, extraction of $\mathrm{DH}$ by protein precipitation followed by liquid-liquid extraction using 5\% IPA in n-Hexane as extraction solvent was carried out. After this extraction, procedure good results were obtained for $\mathrm{DH}$ and no interference was observed from blank for estimation of DH. In addition, it also showed good recovery of drug from plasma.

\section{Linearity}

Linearity curve shows linearity in the range of $5-105 \mu \mathrm{g} / \mathrm{mL}$ for $\mathrm{DH}$. The correlation coefficient $\left(\mathrm{R}^{2}\right)$ was found to be 0.9965 for $\mathrm{DH}$, which indicates the method is linear. Linearity study of MEM is summarized in Table 1.

\section{Precision}

Intra-day precision and inter-day precision for $\mathrm{DH}$ was performed by analyzing three different concentrations $(\mu \mathrm{g} / \mathrm{mL})$ within linearity ranges and percentage of relative standard deviation $(\% \mathrm{RSD})<10$ shows that the method is precise. Results of intra-day and inter-day precision study are presented in Table 2.

\section{Recovery}

Recovery study was performed by comparing the response of the drug extracted from spiked plasma with pure drug response, and \%RSD was calculated, which shows the accuracy of the method. Summary of recovery study is depicted in Table 3.

Summary of validation parameters for developed method is shown in Table 2.

\begin{tabular}{lccc}
\multicolumn{4}{l}{ Table 1: Calibration curve data of $\mathrm{DH}$} \\
\hline Concentration $(\boldsymbol{\mu g} / \mathrm{mL})$ & Intensity & SD $^{\text {a }}$ & \%RSD \\
\hline 5 & 14.20 & 1.21 & 8.52 \\
25 & 20.06 & 1.37 & 6.87 \\
45 & 26.56 & 1.41 & 5.32 \\
65 & 34.87 & 1.86 & 5.34 \\
85 & 41.15 & 1.72 & 4.19 \\
105 & 46.19 & 1.75 & 3.79 \\
\hline
\end{tabular}

DH: Donepezil hydrochloride, SD: Standard deviation, RSD: Relative standard deviation, Where, $a$ is number of determination, $n=3$

Table 2: Summary of validation parameters

\begin{tabular}{lc}
\hline Parameters & DH \\
\hline Detection wavelength & $389 \mathrm{~nm}$ \\
Linear range $(\mu \mathrm{g} / \mathrm{mL})$ & $5-105$ \\
Correlation coefficient $R^{2}$ & 0.9965 \\
Intra-day precision \%RSD & $\leq 10$ \\
Inter-day precision \%RSD & \\
$\%$ Recovery & $\leq 10$ \\
LOD $(\mu \mathrm{g} / \mathrm{ml})$ & $75-85$ \\
LOQ $(\mu \mathrm{g} / \mathrm{ml})$ & 4.84 \\
\hline
\end{tabular}

DH: Donepezil hydrochloride, RSD: Relative standard deviation, LOD: Limit of detection, LOQ: Limit of quantification, Where, $a$ is number of determination, $\mathrm{n}=3$ 
Table 3: Recovery of DH

\begin{tabular}{lcc}
\hline Concentration $(\boldsymbol{\mu g} / \mathrm{mL})$ & \%Recovery & \%RSD $^{\mathrm{a}}$ \\
\hline 5 & 74.83 & 4.16 \\
25 & 85.10 & 4.86 \\
45 & 81.57 & 3.76 \\
65 & 81.93 & 2.98 \\
85 & 83.33 & 3.67 \\
105 & 79.48 & 3.38 \\
\hline
\end{tabular}

DH: Donepezil hydrochloride, RSD: Relative standard deviation, Where, a is number of determination, $n=3$

\section{CONCLUSION}

The proposed spectrofluorimetric method for estimation of $\mathrm{DH}$ in human plasma found simple, precise, accurate specific, and sensitive. High recovery shows that the method is free from the interference from plasma constituents. Hence, it can be successful applied for the estimation of $\mathrm{DH}$ in human plasma.

\section{REFERENCES}

1. Maryadele O'Neil J. The Merck Index, an Encyclopedia of Chemicals, Drugs and Biologicals. $13^{\text {th }}$ ed. Whitehouse Station, N.J: Merck \& Co. Inc.; 2001. p. 3453.

2. Indian Pharmacopoeia Commission. Indian Pharmacopoeia. Vol. 2. Ghaziabad: Indian Pharmacopoeia Commission; 2010 p. 1248.

3. Sweetman S. Marindale: The Complete Drug Reference. $36^{\text {th }}$ ed. USA: Pharmaceutical Press; 2009. p. 362-7.

4. Jayanna BK, Nagendrappa G, Arunkumar, Gowda N. Spectrophotometric estimation of donepezil hydrochloride in tablets. J Pharm Biomed Sci. 2010;1:1-3.

5. Pappa H, Farrú R, Vilanova PO, Palacios M, Pizzorno MT. A new HPLC method to determine Donepezil hydrochloride in tablets. J Pharm Biomed
Anal. 2002;27:177-82.

6. Kafkala S, Matthaiou S, Alexaki P, Abatzis M, Bartzeliotis A, Katsiabani M. New gradient high-performance liquid chromatography method for determination of donepezil hydrochloride assay and impurities content in oral pharmaceutical formulation. J Chromatogr A. 2008;1189:392-7.

7. Abonassif MA, Hefnawy MM, Kassem MG, Mostafa GA. Determination of donepezil hydrochloride in human plasma and pharmaceutical formulations by HPLC with fluorescence detection. Acta Pharm. 2011;61:403-13.

8. Nakashima K, Itoh K, Kono M, Nakashima MN, Wada M. Determination of donepezil hydrochloride in human and rat plasma, blood and brain microdialysates by HPLC with a short C30 column. J Pharm Biomed Anal. 2006;41:201-6.

9. Apostolou C, Dotsikas Y, Kousoulos C, Loukas YL. Quantitative determination of donepezil in human plasma by liquid chromatography/ tandem mass spectrometry employing an automated liquid-liquid extraction based on 96-well format plates. Application to a bioequivalence study. J Chromatogr B Analyt Technol Biomed Life Sci. 2007;848:239-44.

10. Xie Z, Liao Q, Xu X, Yao M, Wan J, Liu D. Rapid and sensitive determination of donepezil in human plasma by liquid chromatography/tandem mass spectrometry: Application to a pharmacokinetic study. Rapid Commun Mass Spectrom. 2006;20:3193-8.

11. Shah HJ, Kundlik ML, Pandya A, Prajapati S, Subbaiah G, Patel CN, et al. A rapid and specific approach for direct measurement of donepezil concentration in human plasma by LC-MS/MS employing solid-phase extraction. Biomed Chromatogr. 2009;23:141-51.

12. Jagadeeswaran M, Natesan G, Murugananthan G, Rajagounden R, Mani G, Thangavel S. A validated HPTLC method for the estimation of donepezil HCL in bulk and its tablet dosage form. Eurasian J Anal Chem. 2011;6:40-5.

13. Radwan MA, Abdine HH, Al-Quadeb BT, Aboul-Enein HY, Nakashima K. Stereoselective HPLC assay of donepezil enantiomers with UV detection and its application to pharmacokinetics in rats. J Chromatogr B Analyt Technol Biomed Life Sci. 2006;830:114-9.

14. International Conference on Harmonization; Validation of Analytical Procedures: Text and Methodology, ICH Harmonised Tripartite Guideline Q2(R1); 1995.

15. U.S. Food and Drug Administration. Guidance for Industry: Bioanalytical Method Validation. September, 2013. 